\title{
Incorporation Of Community Law To The Spanish Public Sector Procurement Law Of 2007
}

Patricia Domínguez Alonso, Ph.D., University of Castilla-La Mancha, Spain

\begin{abstract}
The work carries out an analysis of the aims of the new Spanish law regarding Public Sector Contracts, which go beyond the necessary measures required in order to incorporate Directive 2004/18, as well as the major reforms introduced by the new legislation. The change of perspective which European Community law had imposed for many years in this sector and the modest introduction of electronic media, data processing and data transmission in recruitment procedures.
\end{abstract}

Keywords: Public Procurement; European Directives; Spanish Legislation

\section{INTRODUCTION: DECISIVE INFLUENCE FROM EUROPEAN UNION ON THE RECENT EVOLUTION OF SPANISH LAW ON PUBLIC PROCUREMENT}

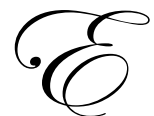

uropean Community law has decisively influenced the development and recent evolution of Spanish legislation on public procurement. Since Spain entered the European Community in 1986, the legislative norms on public procurement have been to a great extent the transposition of Community directives on this matter.

Above other objectives which are in many occasions more emphasized by the Spanish legislator (such as the fight against corruption or the improvement and simplification of procurement procedures), the adaptation of Spanish law to Community directives and case-law on public procurement constituted the direct and immediate cause for approving the norm which marked a turning point on the matter: Ley 13/1995, de 18 de mayo, de Contratos de las Administraciones Públicas (LCAP), which substituted the former Ley de Contratos del Estado de 8 de abril de 1965 (LCE) and whose main objective was the implementation of Directives 92/50, 93/36 and 93/37/EEC, concerning the award of public service contracts, public supply contracts and public works contracts respectively.

Also approving the present Ley 30/2007, de 30 de octubre, de Contratos del Sector Público (LCSP) is the response as primary objective to the Spanish Government need of implementing the provisions of Community Directive 2004/18/EC of 31 March 2004, on the coordination of procedures for the award of public works contracts, public supply contracts and public service contracts. This is also the case of Ley 31/2007, de 30 de octubre, which is the applicable norm regulating procurement procedures of entities operating in the water, energy, transport and postal services sectors, which incorporates the provisions established by Directive 2004/17/EC.

\section{THE CHANGE OF APPROACH NECESSARY TO ANALYZE AND APPLY SPANISH LEGISLATION ON PUBLIC PROCUREMENT}

At last the LCSP has incorporated to Spanish law on public procurement the change of perspective which European Community law had imposed for many years in this sector although Spanish legislation was resisting to fully assume it (GARCÍA DE ENTERRÍA, 2004). This can explain the reason why the new Law defines in the core article 1 its purpose and objective by refering to the general principles of free access to tenders, publicity and 
transparency of procedures and non discrimination and equal treatment of candidates.

In contrast to the Spanish tradition, extended to the LCAP, which emphasized as fundamental objective of the legislation on this matter the guarantee of public interests within the contract, with the legislation based on the figure of administrative contracts and in defence of public prerrogatives in the contracts, the LCSP is directly founded in Community law on procurement and its main purpose is to ensure non discrimination in awarding procedures in order to guarantee the establishment of the home market and to avoid unfair competition (see MEILÁN GIL, J.L., 2008, p. 93 and following).

According to article 1 of the LCSP aforementioned, the main norm in Spanish procurement legislation which is also applied due to its character as public legislation to all authorities, bodies and public entities in Spain, in conjunction with the guarantee of equal treatment, publicity and transparency establishes as novel objectives of the norm " to ensure, in conexion with the aim of budgetary stability and expenditure control, the efficient use of funds destined to works execution, acquisition of goods and to contract services by requiring previous definition of the needs to be satisfied, the safeguard of free competition and the selection of the most economically advantageous tender".

This explains that when the LCSP points out in subparagraph 2 of the said article 1 that "the purpose of this law is also the regulation of the legal status applicable to the effects, execution and termination of administrative procurement contracts, considering the institutional ends of public character pursued by those goals", it recognizes the secondary and partial role of this norm with respect to its main objectives stated in the previous paragraph. Thus prerrogatives or exorbitant clauses can only be applied to some of the public contracts concluded by public administrations, typical or special administrative contracts, and not to contracts concluded by the remaining awarding authorities and public sector entities, which, on the contrary, are under the general principles of public procurement and must therefore respect the rules derived from free competition (exorbitant clauses of the Administration in administrative contracts are stated in Chapter II, Title I of Book IV of the LCSP -articles 194 and 195-).

In summary, the principles of objectivity, transparency, publicity and non discrimination based on National rules and Community rules of constitutional nature indisputably prevail nowadays over any other normative function on procurement. These principles constitute at present the foundation of all public rules on procurement and are characterized by their transversality as they cover and are manifest in all stages of the contract - preparation and performance- in contrast to, for example, European Directives on procurement contracts or to WTO Agreement on Government Procurement regulating mainly the stages of preparation and awarding of contracts-.

\section{ADEQUATE BUT LIMITED INTRODUCTION OF ELECTRONIC, COMPUTERIZED AND TELEMATIC MEANS IN PROCUREMENT PROCEDURES}

It is unquestionably positive that the LCSP has opted for the maximum application of Directive 2004/18 concerning electronic purchasing systems, section which that directive had left at the discretion of each Member State concerning the incorporation of different procedures and requirements.

Indeed, the lack of coherence with the intended impulse on electronic purchasing systems by Directive 2004/18 can be criticised as it did not impose forceful transposition concerning these means into the different national systems, thus allowing Member States to choose whether contracting authorities may use any option proposed; but of course establishing that once the transposition had been performed this should be carried out under the terms defined and regulated by this Directive. This is expressly stated in whereas 16 of Directive 2004/18/EC: 'In order to take account of the different circumstances obtaining in Member States, Member States should be allowed to choose whether contracting authorities may use framework agreements, central purchasing bodies, dynamic purchasing systems, electronic auctions or the competitive dialogue procedure, as defined and regulated by this Directive'.

The decision by the Spanish legislator on this matter is correct but it could still have been better if the law had decided to go beyond Community norms and truly support the use of electronic means in public procurement, 
in line with the regulations established by the relevant Law 11/2007 of 22 June, concerning electronic access to Public Services by citizens, which improving the outdated LRJPAC (Law on the legal system of Public Administrations and ordinary administrative procedures) regarding electronic aspects, establishes the relation with Public Administrations using electronic means as a right for citizens and a correlative obligation for the Administrations. Moreover, this law also establishes a time period for application of this right, which in the scope of the General Administration of the State and its dependent public bodies shall be exercised in relation to all procedures and acts under their competence from January December 2009. However the Spanish LCSP has not moved forward to perform the necessary review of the traditional procurement procedure.

Nowadays the service to citizens requires the establishment of their right to communicate with the Administrations using electronic means, and the sector of goods and services purchase by Public Administrations and their dependent or related bodies or entities seems specially indicated for the use of ICT. For this reason in the new strategic framework 'i2010, European Information Society 2010', which boosts an open and competitive digital economy and highlights the impulse of ICT for the promotion of inclusion and quality of life, public procurement is considered a key sector to be promoted in order to achieve better public services which are more accessible and more profitable.

Moreover the introduction of electronic and telematic means in procurement procedures shall mean a great increase of transparency and efficiency in procurement procedures for the Administrations. As highlighted by the Communication of the Commission on the role of the electronic Administration (e-government) in the future of Europe of 26 September 2003, the use of information technologies and communications may increase quality and efficiency of public procurement apart from implying significant savings for taxpayers and may also contribute to improve relations with suppliers, satisfaction of users, the use of human resources in procurement procedures and transparency of public expenditure.

These evident advantages of the use of telematic and electronic means in public procurement which had long been emphasized by Community institutions, makes less understandable and more criticisable that, apart from the good declaration of intentions, the European Union has not approved up to the present moment firm and clear resolutions for the development of electronic public procurement. In this sense, procurement directives of 2004 are just a timid approximation that despite including specific norms concerning electronic procedures for the award of public contracts, still leaves far behind the full diffusion of electronic public procurement in Europe.

The Spanish LCSP, using a legislative and systematic technique not very adequate, states in two additional dispositions the regulations of the main aspects concerning the use of electronic, computerized and telematic means in procurement procedures, as mentioned previously, one of the main new contributions from that law, directly influenced by Community law. These general rules should have been included within the articles of the norm and could have been situated next to other precepts of that law concerning the use of telematic means under a specific chapter, thus facilitating LCSP users its application and use.

\section{AUTHOR INFORMATION}

Patricia Domínguez Alonso, PhD in Law by Autonoma University of Mexico State and Degree in Law by University of Castilla-La Mancha. Asistent Professor of Administrative Law at Public Law Department. Faculty of Social Sciences of Cuenca. University of Castilla-La Mancha (Spain). E-mail: Patricia.Dominguez@uclm.es.

Research Interest: Environmental law, Water Law, administrative organization.

\section{REFERENCES}

1. García E. (2004): “Ámbito de aplicación de la Ley”, in AAVV, Comentarios a la Ley de Contratos de las Administraciones Públicas, Civitas, Madrid, $2^{\mathrm{a}}$ ed.

2. Gil, J. L. (1998): Procedimientos y formas de adjudicación de los contratos administrativos, La LeyActualidad, Madrid. 
3. Gimeno, J .M. (2008): "El nuevo ámbito subjetivo de aplicación de la Ley de Contratos del Sector Público", Revista de Administración Pública, 176 (2008).

4. Gimeno, J. M. (2010): Novedades de la Ley de Contratos del Sector Público de 30 de octubre de 2007 en la regulación de los procedimientos de adjudicación de los contratos públicos, Civitas, Pamplona.

5. Meillán, J. L. (2008): La estructura de los contratos públicos. Norma, acto y contrato, Ed. Iustel, Madrid.

\section{NOTES}

